\title{
Cinta Merek Sebagai Mediasi Antara Kepercayaan Merek, Gairah Merek Dan Niat Beli Kembali
}

\author{
Kadarusman $^{1 *}$, Evi Maria'), Dwi Danesty Deccasari ${ }^{1)}$ \\ STIE Malangkucecwara \\ Jl. Terusan Candi Kalasan, Blimbing, Mojolangu, Kota Malang, Jawa Timur 65142, Indonesia \\ *E-mail : kadarusman@stie-mce.ac.id
}

\begin{abstract}
Artikel Info
ABSTRAK

Dikirim:

6 September 2019

Revisi:

15 September 2019

Diterima:

Tujuan dari penelitian ini adalah untuk menguji pengaruh antara brand passion, brand trust terhadap repurchase intention dengan brand love sebagai variabel mediasi. Hasil penelitian menunjukan bahwa secara langsung brand passion, brand trust berpengaruh secara signifikan dan positif terhadap brand love. Brand passion, brand trust dan brand love secara langsung berpengaruh signifikan dan positif terhadap repurchase intention. Brand love menjadi variabel yang memediasi pengaruh antara brand 28 September 2019 passion dengan repurchase intention, dengan sifat mediasi adalah full mediation. Brand love juga menjadi variabel yang memediasi pengaruh antara brand trust dengan repurchase intention dengan sifat mediasi full mediation. meningkatnya gairah dan kepercayaan terhadap merek akan meningkatkan rasa cinta pada merek tersebut yang pada akhirnya akan membuat konsumen melakukan pembelian kembali.
\end{abstract}

Kata Kunci: brand passion, brand trust, brand love, repurchase intention

\section{Brand Love as Mediation Between Brand Trust, Brand Passion and Repurchase Intention}

\begin{abstract}
The purpose of this study was to examine the effect of brand passion, brand trust on repurchase intention and brand love as a mediating variable. Brand passion, brand trust and brand love directly have a significant and positive effect on repurchase intention. Brand love is a variable that mediates the influence between brand passion and repurchase intention, with the nature of mediation is full mediation.Brand love is also a variable that mediates the influence between brand trust and repurchase intention with the full mediation nature of mediation. Increased passion and trust in the brand will increase the love for the brand which will ultimately make consumers make purchases.
\end{abstract}

Keyword: Brand passion, brand trust, brand love, repurchase intention

\section{Cara Sitasi :}

Kadarusman., Maria., E., \& Deccasari, D. D. (2019). Cinta Merek Sebagai Mediasi Antara Kepercayaan Merek, Gairah Merek Dan Niat Beli Kembali. Jurnal Ilmiah Manajemen dan Bisnis, 20(2), 92-105. https://doi.org/10.30596/jimb.v20i2.3466. 


\section{PENDAHULUAN}

Merek merupakan aset yang sangar berharga bagi perusahaan dan merupakan dasar mencapai keunggulan kompetisi (competititive advantage) dan mendapatkan keuntungan, sehingga fokus strategi pemasaran dari penjualan langsung ke strategi membangun hubungan antara konsumen dan merek (Sahin, Cemal, \& Hakan, 2012). Kepuasan dan sikap positif konsumen terhadap merek tidak lagi memadai tetapi perlu menghubungkan konsumen-merek dengan lebih emosional dan efektif (Cristina, Gómez, \& Pérez, 2018). Banyaknya merk yang beredar di masyarakat menjadikan persaingan merk di pasar menjadi semakin tinggi karena konsumen mempunyai banyak pilihan dalam memuaskan keinginan dan kebutuhannya. Para praktisi dan akademisi pemasaran sepakat hubungan konsumen dan merek akan menjadikan konsumen emosional terhadap merek tertentu merupakan kekuatan pendorong keberhasilan sebuah merek. Hubungan konsumen dan merek sangat dipengaruhi oleh emosi, budaya dan pengalaman terhadap merek favorit mereka, sehingga hubungan konsumen merek bersifat personal.

Merek mempunyai arti yang berbeda pada orang yang berbeda sesuai dengan pengalaman dan budaya yang mereka miliki, sehingga konsumen membuat koneksi dengan merek tertentu yang paling mewakili sesuai dengan status individu dan sosialnya(Albert, Merunka, \& Valette-florence, 2013; Pourazad, Pare, \& Saniee, 2015). Niyomsart \& Khamwon, (2016) berpendapat bahwa hubungan konsumen merek dibagi menjadi 4 tingkatan yaitu, 1) kepercayaan (Confidence) adalah merek yang dapat dipercaya dan menepati janji pada konsumen, 2) integritas (integrity) merek yang membuat konsumen merasa merek tersebut dapat menyelesaikan masalahnya dan dihargai, 3) kebanggaan (pride) adalah merek yang membuat kebanggaan pada konsumen, 4) gairah (passion) adalah tingkat tertinggi dalahm hubungan konsumen merek, yang merupakan nilai dimana konsumen merasa jatuh cinta terhadap merek tersebut yang tidak dapat digantikan oleh merek lainnya. Hal tersebut menjadikan konsumen selalu melakukan pembelian berulang.

Penelitian terdahulu menunjukan bahwa ekspresi diri, kepercayaan merek dan nilai suatu hedonis suatu merek terbukti sebagai anteseden terhadap cinta merek (Albert et al., 2013; Batra, Ahuvia, \& Bagozzi, 2012). Kepercayaan merupakan pendorong utama cinta merek (Morgan \& Hunt, 1994). Konsumen yang cinta merek cenderung lebih puas pada produk hedonik daripada utilitarian, disamping itu cinta merek juga menunjukan hubungan yang positif terhadap kesetiaan terhadap merek dan positif word of mouth (Carroll \& Ahuvia, 2006). Cinta merek juga mempengaruhi secara baik terhadap kesetiaan terhadap merek, kata-kata positif dari mulut ke mulut, niat beli kembali yang lebih kuat, dan kemauan lebih besar untuk membayar dengan harga premium dan sikap menerima produk yang gagal (Carroll \& Ahuvia, 2006; Fetscherin, 2014; Grisaffe \& Nguyen, 2011; Karjaluoto, Munnukka, \& Kiuru, 2016; Kudeshia, Sikdar, \& Mittal, 2016).berdasarkan penelitian Batra et al., (2012) dan Kudeshia et al., (2016) kata-kata positif dari mulut ke mulut merupakan hasil dari cinta merek, tetapi penelitian belum memberikan informasi yang menyeluruh tentang bagaimana kepercayaan merek, kesesuaian diri, merek produk hedonis, dan cinta merek bersama-sama mendorong WOM dalam saluran offline dan online. Penelitian lain juga menunjukan bahwa dampak gairah merek terhadap perilaku individu termasuk loyalitas pembelian dan ketidakpekaan harga (Pourazad et al., 2015).

Cinta merek (brand love) merupakan konsep yang membuat konsumen mencintai dengan hasrat dan kepuasan terhadap merek produk atau layanan tertentu. Cinta merek 
(brand love) adalah tingkat keterikatan emosioanal yang menggelora dan bergairah yang ada pada konsumen yang puas atas merek tertentu (Batra et al., 2012; Carroll \& Ahuvia, 2006). Konsumen yang secara emosional memiliki perasaan cinta terhadap merek atau lebih dari sekedar menyukai merek, membuat tingkat loyalitas dan word of mouth positif semaikin tinggi (Batra et al., 2012; Carroll \& Ahuvia, 2006) yang pada akhirnya jika konsumen membutuhkan barang yang sama akan melakukan pembelian kembali pada merek yang sama (Cristina et al., 2018; Sahin et al., 2012)

Kepercayaan merek (brand trust) merupakan Konstruk kunci dalam pemasaran relasional dimana kepercayaan merek memberikan komponen penting hubungan konsumen-merek, kepercayaan mencerminkan asumsi tentang keandalan, kejujuran dan altruisme yang atribut konsumen atribut untuk merek (Hess, 1995). Kepercayaan merek (brand trust) adalah tingkat kepercayaan konsumen tentang suatu merek telah memenuhi keinginannya (Chinomona \& Maziriri, 2013). Konstruk ini meliputi elemen kognitif dan afektif (Delgado-Ballester et al., 2003). Dimensi kognitif menunjukkan persepsi bahwa merek akan memenuhi harapan dan menghormati kewajibannya (Chaudhuri dan Holbrook, 2001); dimensi afektif sebaliknya didasarkan pada persepsi kejujuran dan altruisme (Delgado-Ballester et al., 2003). Konsumen yang mempunyai kepercayaan terhadap merek tertentu telah memenuhi keinginannya cenderung akan membuat konsumen mencintai merek tersebut yang pada gilirannya akan menciptakan niat membeli kembali (repurchase intention). Tetapi menurut (Chao, et al., 2011) trust tidak signifikan terhadap niat beli palnggan.

Kemungkinan membeli kembali (repurchase likelihood) merupakan proses pembelian dari perusahaan yang sama atas barang dan jasa dari perusahaan tersebut, yang didasari oleh alasan membeli kembali karena pengaman masa lalu (Qian, Peiji, \& Quanfu, 2011). Kemungkinan membeli kembali (repurchase likelihood) merupakan penilaian individu tentang niat kembali kembali dari perusahaan yang sama, berdasarkan pengalaman sebelumnya, atau kemungkinan menggunakan merek yang sama pada masa yang akan datang (Sahin et al., 2012). Niat membeli kembali (repurchase intention) merupakan kemungkinan untuk melakukan pembelian kembali (repurchase likelihood) pada merek yang sama(ZeithamI, Berry, \& Parasuraman, 1996). Niat membeli kembali (repurchase intention)kemungkinan membelli membeli kembali dengan harga premium dan kesediaan untuk menyampaikan pengalaman positif melalui word of mouth kepada konsumen potensial yang berencana membeli produk (Bozbay, Karami, \& Arghashi, 2014; ZeithamI et al., 1996). Tingginya niat membeli kembali pelanggan secara ekonomis lebih menguntungkan dibanding harus mencari pelanggan baru (Cristina et al., 2018).

Penelitian tentang perilaku pembelian berpendapat bahwa emosi, pengalaman dan budaya sangat mempengaruhi hubungan antara pelanggan dengan merek favoritnya, sehingga secara psikologis emosi, pengalaman dan budaya mempengaruhi perilaku pembelian dimasa yang akan datang (Bauer, Heinrich, \& Martin, 2007). Gairah merek (brand passion) merupakan sikap afektif yang sangat positif terhadap merek tertentu yang mengarah pada ikatan emosional dan mempengaruhi faktor perilaku yang relevan (Albert et al., 2013; Bauer et al., 2007; Carroll \& Ahuvia, 2006). Sikap konsumen secara emosi positif terhadap merek mempengaruhi perilaku konsumen terhadap gairah merek (brand passion) yang pada akhirnya mempengaruhi kesedian konsumen untuk membayar secara premium, menyampaikan kepada konsumen potensial (word of mouth) dan dan melakukan 
pembelian kembali. Hasil penelitian Bauer et al., (2007) menunjukan bahwa extraversion tidak berpengaruh significant terhadap brand passion. Sedangkan pada penelitian yang sama Bauer et al., (2007)brand passion berpengaruh significant terhadap word of mouth, price premium, dan repurchase intention. Dalam teori cinta yang dikemukan oleh (Steinberg, 1986) yang terkenal dengan triangular theory of love terdapat tiga komponen utama dalam membentuk cinta, yaitu intimacy (kedekatan), passion (hasrat) dan commitment (komitmen). Intimacy (kedekatan) merupakan adanya perasaan dekat, terhubung, tertarik dalam hubungan cinta, sedangkan passion (hasrat) merupakan gairah yang mendorong pada arah ramantis, ketertarikan pada fisik dan seksual dan commitment (komitmen) dalam jangka pendek merupakan keputusan untuk saling mencintai dan dalam jangka panjang saling komitmen untuk mempertahankan cinta (Steinberg, 1986)

Kepercayaan merek (brand trust)sangat penting bagi bidang pemasaran karena sebagai penentu dan pengaruhnya terhadap komitmen. Kepercayaan merek (brand trust) mengacu pada ekspektasi konsumen tentang keandalan merek dalam situasi berisiko atau kesediaan konsumen untuk bergantung pada merek (Albert et al., 2013). Kepercayaan merek (brand trust) perasaan aman konsumen dalam interaksinya dengan merek, yang didasarkan pada persepsi konsumen bahwa merek tersebut dapat diandalkan dan bertanggungjawab untuk kepentingan dan kesejahteraan konsumen (Ballester, 2014).

$$
\text { Carroll \& Ahuvia, }
$$

membandingkan perasaan cinta terhadap objek dengan perasaan cinta antar pribadi, hasil perbandingan menunjukkan hasil bahwa mereka memiliki perasaan yang lebih umum sama, baik cinta antar pribadi maupun cinta terhadap obyek. Cinta antar pribadi membutuhkan kedua belah pihak untuk saling mencintai, tetapi cinta terhadap benda seperti merek oleh konsumen tidak membutuhkan kedua belah pihak tetapi konsumen tetap punya hasrat cinta terhadap benda tersebut(Whang, Allen, Sahoury, \& Zhang, 2004). Kekasih menemukan bahwa obyek itu menarik, obyek memberikan sesuatu yang diinginkan dan dibutuhkan, rasa cocok secara alami dan cinta abadi daripada adanya perbedaan tentang emosi negatif, cinta terhadap obyek dan pengorbanan diri. Cinta terhadap merek merupakan derajat keterikatan secara emosional dipenuhi perasaan gairah yang dimiliki oleh konsumen yang merasa puas atas nama dagang tertentu(Batra et al., 2012; Carroll \& Ahuvia, 2006). Lima karakter yang menjadikan kecintaan konsumen terhadap merek, yaitu :1. passion for the brand, 2. attachment for the brand, 3. positive evaluation of the brand, 4.) positive emotions in response to the brand and 5. declaration of love for the brand (Carroll \& Ahuvia, 2006). Cinta merek juga mengarah pada persepsi positif yang bias terhadap merek. (Albert, Merunka, \& ValetteFlorence, 2009) mengidentifikasi enam dimensi orde pertama dari cinta merek idealisasi (idealization), keintiman (intimacy), kesenangan (pleasure), mimpi (dream), ingatan (memories), kesatuan) yang membentuk dua dimensi orde kedua (gairah dan kasih sayang (unicity). Penelitian menunjukan hasil bahwa brand love berpengaruh positif terhadap word of mouth dan brand loyalty (Carroll \& Ahuvia, 2006).

Niat pembelian kembali merupakan kecenderungan konsumen untuk melakukan pembelian ulang atas barang dan jasa yang telah dikonsumsi dan kecenderungan membagikan pengalaman penggunaannya kepada teman dan kerabat (Brady \& Cronin, 2001; Cronin \& Taylor, 1992; Wang, Lo, \& Department, 2004; ZeithamI et al., 1996). Pembelian kembali merupakan penilaian individu tentang kemungkinan membeli kembali dari perusahaan yang sama yang didasarkan pada pengalaman masa lampu dan 
kemungkinan kejadian masa yang akan dengan pembelian kembali (repurchase intention).

\section{Pengembangan Hipotesis}

Merek yang sudah terkenal dapat meningkatkan kemanfaatan produk dan layanan yang selanjutnya dapat memberikan informasi yang terkait dengan manfaat tersebut melebihi merek lainnya (Hoeffler \& Keller, 2003; Keller, 2009). Merek yang terkenal menjadikan konsumen lebih bergairan yang pada akhirnya dipakai sebagai referensi jika konsumen tersebut malakukan pembelian kembali. Merek menarik bagi konsumen untuk melakukan pembelian kembali atas produk atau layanan dan merek juga membantu menanggulangi perilaku konsumen yang disebabkan adanya ketidakstabilan harga (Foster \& Cadogan, 2000; Yasin, 2013). Merek sangat penting dalam meningkatkan keunggulan kompetisi perusahaan karena merek mudah menarik palanggan dan memiliki pengaruh pada perilaku konsumen serta memotivasi konsumen untuk melakukan pembelian berulang. Sehingga hipotesis pertama adalah sebagai berikut:

H1: Brand passion berpengaruh positif dan signifikan terhadap repurchase intention.

Merek harus dipahami sebagai struktur tidak berwujud, dimana konsumen yang merasa bergairah terhadap suatu merek (brand passion) tertentu dapat mengalami keterkaitan secara emosional dengan merek tersebut. Keterikatan secara emosional tersebut merupakan sebuah rasa adanya cinta terhadap obyek tersebut yaitu merek (brand love)(Carroll \& Ahuvia, 2006; Cristina et al., 2018). Semakin meningkat gairah merek (brand passion) cenderung cenderung semakin meningkat kecintaan konsumen terhdaap merek (brand love), sehinga hipotesis pertama dapat dinyatakan sebgai berikut:
H2: brand passion berpengaruh positif dan signikan terhadap brand love

Secara umum dinyatakan bahwa kepercayaan merek (brand trust) merupakan anteseden dari cinta merek (brand love)(Albert \& Merunka, 2013; Albert \& Valette-Florence, 2010; Karjaluoto et al., 2016). Kepercayaan merek merupakan penghubung antara konsep pengalaman merek dengan loyalitas merek atau kepuasan dan loyalitas merek. Kepercayaan merek merupakan prasyarat yang diperlukan dalam hubungan merek dengan konsumen. Kepercayaan terhadap suatu merek mengarah pada hasil positif seperti sikap positif terhadap merek, komitmen dan loyalitas yang lebih kuat dan merupakan faktor utama yang berkontribusi terhadap cinta merek (Karjaluoto et al., 2016). Sehingga hipotesis ketiga adalah

H3: kepercayaan merek (brand trust) berpengaruh positif dan signifikan dengan cinta merek (brand love)

Kepercayaan dan kepuasan terhadap merek berdampak pada niat membeli kembali. Kepercayaan merek (brand trust) mengacu pada ekspektasi konsumen tentang keandalan merek dalam situasi berisiko atau kesediaan konsumen untuk bergantung pada merek (Albert \& Merunka, 2013). Brand lovemenunjukan efek positif terhadap sikap emosional konsumen untuk melakukan pembelian kembali (Cristina et al., 2018), sehingga hipotesis keempat dan kelima adalah:

H4 : Brand trust berpengaruh positif dan signifikan terhadap repurchase intention

$\boldsymbol{H 5}$ : Brand love berpengaruh positif dan signifikan terhadap repurchase intention

Merek harus dipahami sebagai struktur tidak berwujud, dimana konsumen yang merasa bergairah terhadap suatu merek (brand passion) tertentu dapat mengalami keterkaitan secara emosional dengan merek tersebut. Keterikatan secara emosional tersebut merupakan sebuah rasa adanya cinta 


\section{Jurnal Ilmiah Manajemen dan Bisnis}

terhadap obyek tersebut yaitu merek (brand love)(Carroll \& Ahuvia, 2006; Cristina et al., 2018). Kepercayaan merek (brand trust) mengacu pada ekspektasi konsumen tentang keandalan merek dalam situasi berisiko atau kesediaan konsumen untuk bergantung pada merek (Albert \& Merunka, 2013). Sehingga hipotesis keenam dan ketuju adalah sebagai berikut:

H6: brand love sebagai mediator pengaruh antara brand passion dengan repurchase intention.

$\mathrm{H} 7$ : brand love sebagai mediator antara pengaruh antara brand trust dengan repurchase intention.

Berdasarkan latar belakang dan kajian teori diatas penelitian ini akan menguji model sebagai berikut:

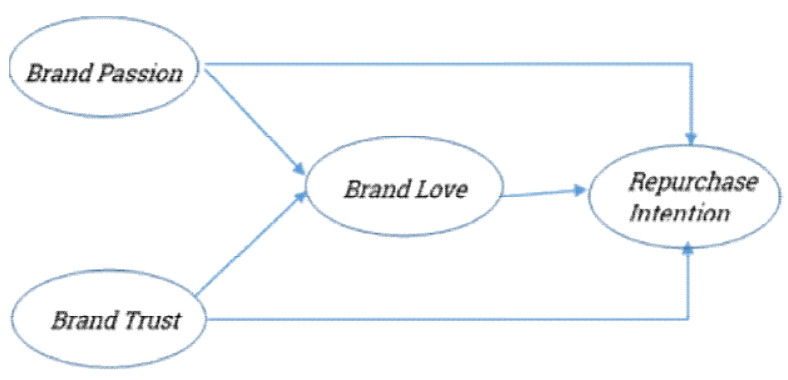

Gambar 1. Model Penelitian

Sumber :: Albert et al., (2013); Carroll \& Ahuvia, (2006); Pourazad et al., (2015), Skoog \& Söderström, (2015), Ruiz-Ortega, et al., (2013)

\section{METODE}

Populasi dalam penelitian ini adalah mahasiswa di Malang yang menggunakan sepeda motor honda. Penelitian analisis jalur yang jumlah populasinya tidak diketahui jumlahnya maka penentuan jumlah sampelnya adalah 10 kali jumlah indikator pertanyaan(Joseph. Hair. JR, William C. Black, Barry J. Babin, 2009; Sekaran, 2003). Jumlah indikator dalam penelitian ini adalah sebanyak 20 indikator sehingga jumlah sampel yang dianggap mewakili populasi adalah sebesar antara 200 sample.
Pengambilan sampel dilakukan dengan non probability sampling dimana kuesioner diberikan pad responden yang kebetulan dijumpai dengan menggunakan sepeda motor merek Honda. Sebanyak 200 kuesioner disebarkan dan yang dapat dianalisis sebesar 194 kuesioner, sehingga respone rate sebesar $97 \%$

Definisi operasional atas variabel yang digunakan dalam penelitian ini adalah sebagai berikut;

Tabel 1. Definisi Operasional

\begin{tabular}{|c|c|}
\hline Variabel laten & Item \\
\hline $\begin{array}{c}\text { Brand passion(Albert et } \\
\text { al., 2009; Batra et al., } \\
\text { 2012) }\end{array}$ & $\begin{array}{l}\text { 1. Saya selalu } \\
\text { membayangkan merek ini } \\
\text { 2. Hubungan saya dengan } \\
\text { merek ini sangat penting } \\
\text { 3. Hubungan saya dengan } \\
\text { Merek ini sangat } \\
\text { romantis } \\
\text { 4. Saya mengagumi Merek } \\
\text { ini, } \\
\text { 5. Saya sering memikirkan } \\
\text { tentang Merek ini setiap } \\
\text { saat }\end{array}$ \\
\hline $\begin{array}{l}\text { Brand trus } \\
\quad \text { (Zboja \& Voorhees, } \\
\text { 2006) }\end{array}$ & $\begin{array}{l}\text { 1. Dapat dipercaya setiap } \\
\text { saat. } \\
\text { 2. Dapat diandalkan untuk } \\
\text { melakukan apa yang } \\
\text { benar } \\
\text { 3. Memiliki integritas tinggi. } \\
\text { 4. Kompeten. } \\
\text { 5. Sangat bisa diandalkan. } \\
\text { Responsif }\end{array}$ \\
\hline
\end{tabular}

Brand love(Niyomsart \& $1 . \quad$ Merek yang luar biasa.

Khamwon, 2016) 2. Membuat saya merasa baik.

3. Merek ini benar-benar mengagumkan.

4. Merek ini membuat saya sangat gembira.

5. Saya suka merek ini.

6. Merek ini membuat saya sangat senang

\begin{tabular}{crl}
\hline Repurchase & 1. & $\begin{array}{l}\text { Di masa depan, saya } \\
\text { akan menggunakan }\end{array}$ \\
Intention(Brady \& & & merek ini lagi. \\
Cronin, 2001; Cronin \& & 2. & Di masa depan, saya \\
Taylor, 1992; Kuo, & akan \\
Wub, \& Deng, 2009; & merekomendasikan \\
ZeithamI et al., 1996) & merek ini. \\
& 3. $\begin{array}{l}\text { Di masa depan, saya } \\
\text { akan terus } \\
\end{array}$ & menggunakan merek ini \\
\hline
\end{tabular}


Metode analisis menggunakan SEM PLS, yang diuji dengan, outer model (model pengukuran) dan ujiinner model (model struktural). Outer model terdiri dari uji validitas dan uji reliabilitas. Uji validitas terdiri dari, pertamaadalah convergent validity merupakan uji untuk memastikan bahwa semua indikator yang digunakan dalam penelitia ini mampu dpahami oleh responden. Uji convergent validity diukur dengan nilai loading factor, dengan syarat dapat dikatan valid, jika nilainya $>0,7$ tetapi nilai loading factor $>0,6$ dapat diterima jika nilai AVE dari variabel tersebut $>0,5$ (Joseph. Hair. JR, William C. Black, Barry J. Babin, 2009). Kedua, adalah uji discriminant validitydiuji denganCross loading dengan membandingkan nilailoading factormasingmasing item pada variabel latennya harus lebih besar jika dibandingkan dengan nilailoading factor item variabel tersebut dengan variabel laten lainnya. Uji discriminant validity juga bisa diukur denganAverage variance extracted (AVE) adalahnilai yang interkorelasi internal. AVE adalah rata-rata korelasi antar item.Average variance extracted (AVE) dapat dikatakan valid jika nilai AVE $>0.5$ (Asyraf \& Afthanorhan, 2013; Joseph. Hair. JR, William C. Black, Barry J. Babin, 2009; Tenenhaus, Vinzi, Chatelin, \& Lauro, 2005).

Uji reliabilitas digunakan untuk menentukan apakah alat ukur telah melakukan fungsinya untuk mengukur secara handal dan akurat. Reliabilitas dapat diukur dengan compostie reliability dan dikatan reliabel jika nilai dari composite reliability> 0,7 dan cronbach alpha $>0,5$ (Asyraf \& Afthanorhan, 2013; Joseph. Hair. JR, William C. Black, Barry J. Babin, 2009; Joseph F. Hair, Hult, Ringle, \& Sarstedt, 2017). Uji reliabilitas merupakan uji yang menunjukkan bahwa item (indikator) dari masing-masing variabel mempunyai korelasi yang tingg.

Inner modeldigunakan untuk, pertama adalah uji model dan yang kedua uji hipotesis. Uji model terdiri dari uji $\mathrm{R}^{2}$,Prediction relevance $\left(Q^{2}\right)=1-\left(1-\mathrm{R} 1^{2}\right)$ $\left(1-\mathrm{R} 2^{2}\right) \ldots\left(1-\mathrm{Rn}^{2}\right)$, dan uji Goodness of Fit (GoF). nilaiPrediction relevance $\left(Q^{2}\right)$ masingmasing $0,02,0,15,0,35$ menunjukkan nilai kecil, sedang dan besar (Joseph F. Hair et al., 2017)sedangkan Goodness of fit (GoF) = (Rata-rata AVE $\mathrm{x}$ rata-rata $\mathrm{R}^{2}$ ), dengan syaratnilai $\mathrm{GoF}$ kecil $=0,1$, GoF medium $=$ 0,2 dan GoF besar $=0,38$ (Tenenhaus et al., 2005) dan kedua dilakukan uji hipotesis yang diajukan dalam penelitian.

\section{HASIL DAN PEMBAHASAN}

Penelitian ini menggunakan data primer dengan menyebar sebanyak 200 kuesioner, dari kuesioner tersebut yang biasa dianalisis sebanyak 194 kuesioner dengan respon rate sebesar 97\%. Kuesioner yang tidak bisa dianalsiis karena diisi tidak lengkap, pada saat membawa sepeda motor merek honda ternyata pinjam dari temannya. Jumlah mahasiswa sebanyak 108 atau 56\% dan Mahasiswi sebanyak 86 atau 44\%.

1. Uji Outer model

Uji outer model (model struktural) ini dimaksudkan untuk menguji validitas dan reliabilitas.

Tabel 2. Pengujian validitas dan reliabilitas

\begin{tabular}{|c|c|c|c|c|c|c|c|c|}
\hline & \multicolumn{4}{|c|}{ Loading Factor Dan Cross Loading } & \multirow[t]{2}{*}{ AVE } & \multirow{2}{*}{$\begin{array}{c}\text { Communa } \\
\text { lity }\end{array}$} & \multirow{2}{*}{$\begin{array}{l}\text { Composite } \\
\text { Reliability }\end{array}$} & \multirow{2}{*}{$\begin{array}{l}\text { Cronbach } \\
\text { Alpha }\end{array}$} \\
\hline & Love & Passion & Repurchase & Trust & & & & \\
\hline & \multirow{2}{*}{\multicolumn{3}{|c|}{ BRAND LOVE }} & & \multirow{7}{*}{0.565} & \multirow{7}{*}{0.565} & \multirow{7}{*}{0.886} & \multirow[t]{7}{*}{0.846} \\
\hline Love 1 & 0.728 & & 0.677 & 0.606 & & & & \\
\hline Love 2 & 0.763 & 0.614 & 0.538 & 0.642 & & & & \\
\hline Love 3 & 0.708 & 0.593 & 0.618 & 0.504 & & & & \\
\hline Love 4 & 0.745 & 0.579 & 0.553 & 0.541 & & & & \\
\hline Love 5 & 0.803 & 0.494 & 0.591 & 0.636 & & & & \\
\hline \multirow{2}{*}{\multicolumn{5}{|c|}{$\begin{array}{c}\mathbf{0 . 7 6 0} 0.623 \\
\text { BRAND PASSION }\end{array}$}} & & & & \\
\hline & & & & & \multirow{6}{*}{0.619} & \multirow{6}{*}{0.619} & \multirow{5}{*}{0.890} & \multirow{6}{*}{0.845} \\
\hline Passion 1 & 0.479 & 0.675 & 0.367 & 0.432 & & & & \\
\hline Passion 2 & 0.631 & 0.839 & 0.528 & 0.572 & & & & \\
\hline Passion 3 & 0.577 & 0.809 & 0.438 & 0.473 & & & & \\
\hline Passion 4 & 0.625 & 0.775 & 0.510 & 0.609 & & & & \\
\hline \multirow[t]{2}{*}{ Passion 5} & & 0.825 & 0.626 & 0.544 & & & & \\
\hline & \multicolumn{3}{|c|}{$\begin{array}{l}\text { REPURCHASE INTENTION } \\
\text {. }\end{array}$} & & \multirow[t]{3}{*}{0.556} & \multirow[t]{4}{*}{0.556} & \multirow[t]{4}{*}{0.790} & \multirow[t]{4}{*}{0.608} \\
\hline Reprc. 1 & 0.459 & 0.422 & 0.713 & 0.382 & & & & \\
\hline Reprc. 2 & 0.683 & 0.491 & 0.784 & 0.590 & & & & \\
\hline \multirow[t]{2}{*}{ Reprc.3 } & \multirow{2}{*}{\multicolumn{3}{|c|}{$\begin{array}{l}0.546 \quad 0.513 \\
\text { BRAND TRUST }\end{array}$}} & 0.451 & \multirow{8}{*}{0.563} & & & \\
\hline & & & & & & \multirow[t]{7}{*}{0.563} & \multirow[t]{7}{*}{0.885} & \multirow[t]{7}{*}{0.845} \\
\hline Trust 1 & 0.538 & 0.451 & 0.495 & 0.743 & & & & \\
\hline Trust 2 & 0.577 & 0.560 & 0.549 & 0.765 & & & & \\
\hline Trust 3 & 0.523 & 0.399 & 0.361 & 0.697 & & & & \\
\hline Trust 4 & 0.651 & 0.493 & 0.511 & 0.790 & & & & \\
\hline Trust 5 & 0.602 & 0.496 & 0.473 & 0.741 & & & & \\
\hline Trust 6 & 0.670 & 0.606 & 0.517 & 0.764 & & & & \\
\hline
\end{tabular}

Semua loading factor masing-masing indikator nilainya $>0.7$, kecuali indikator passion 1 pada variabel brand passion sebesar 0,675 dan inikator trust 3 pada variabel brand 
trust sebesar 0,697, tetapi nilai AVE semua varibel > dari 0,5, sehingga berdasarkan kriteria (Joseph. Hair. JR, William C. Black, Barry J. Babin, 2009)dapat disimpulkan bahwa dengan kriteria loading factor semua indikator menjadi pengukur yang baik. Nilai loading factor masing-masing item pada variabel latennya lebih besar jika dibanding dengan nilai loading factor item pada variabel laten lainnya, sehingga bisa disimpulkan bahwa berdasarkan pengujian cross loading terjadi homoginitas masing-masing item terhadap konstruk latennya. Nilai AVE dan Communality $>0.5$ sedangkan nilai composite reliability $>0.7$ dan nilai cronbach alpha $>$ 0.5. Sehinggadapat disimpulkan bahwa semua alat ukur dapat mengukur apa yang seharusnya diukur dengan baik. pengujiancomposite reliability $>0.7$ dan cronbach alpha $>0.5$, menunjukan bahwa alat ukur telah mengukur secara akurat dan konsisten dalam melakukan pengukuran.

2. Inner Model

a. Pengujian model

Hasil dari nilai $\mathrm{R}^{2}, \mathrm{Q}^{2}$ dan $\mathrm{GoF}$ adalah sebagai berikut:

Tabel 2. $\mathrm{R}^{2}, \mathrm{Q}^{2}, \mathrm{GoF}$

\begin{tabular}{cccc}
\hline & R Square & $\mathbf{Q}^{\mathbf{2}}$ & $\mathbf{G o F}$ \\
\hline $\begin{array}{c}\text { Love } \\
\text { Passion }\end{array}$ & 0,732 & & \\
$\begin{array}{c}\text { Repurchase } \\
\text { Trust }\end{array}$ & 0,601 & 0,893 & 0,619 \\
\hline
\end{tabular}

Predictive relevance $\left(\mathrm{Q}^{2}\right)=1-(1-0,732) \mathrm{x}$ $(1-0,601)=0,893 ; \mathrm{GoF}=$ akar dari ratarata AVE x rata-rata $R^{2}$

$$
\begin{aligned}
& =(0,576 \times 0,666)^{\mathbf{0 , 5}} \\
& =0,619
\end{aligned}
$$

Nilai predictive relevance $0,893>0,35$ sehingga dapat disimpulkan bahwa variabel prediktor mempunyai daya prediktif yang tinggi. Sedangkan nilai GoF sebesar 0,619> 0,38 , sehingga dapat disimpulkan bahwa model kuat (robust), dan model tersebut dapat digunakan untuk pengujian hipotesis selanjutnya.

b. Pengujian hipotesis dan analsis

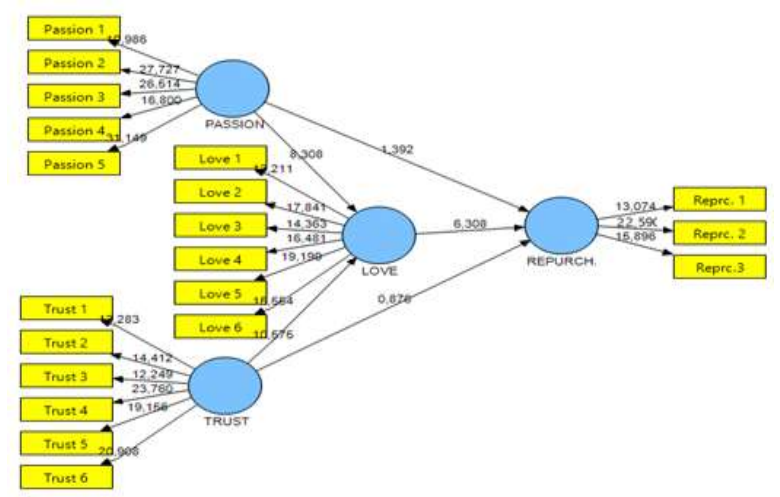

Gambar 2: Hasil uji dengan bootstrapping

\begin{tabular}{|c|c|c|c|c|c|c|}
\hline & $\begin{array}{c}\text { Origi } \\
\text { nal } \\
\text { Samp } \\
\text { le }(O)\end{array}$ & $\begin{array}{c}\text { Samp } \\
\text { le } \\
\text { Mean } \\
(M)\end{array}$ & $\begin{array}{c}\text { Stand } \\
\text { ard } \\
\text { Devia } \\
\text { tion } \\
\text { (STD } \\
\text { EV) }\end{array}$ & $\begin{array}{c}\text { Stand } \\
\text { ard } \\
\text { Error } \\
(S T E \\
\text { RR) }\end{array}$ & $\begin{array}{c}T \\
\text { Statisti } \\
c s \\
|| O / S T \\
E R R \mid\end{array}$ & keputusan \\
\hline \multicolumn{7}{|c|}{ Total effects } \\
\hline $\begin{array}{l}\text { Love -> } \\
\text { Repurchase }\end{array}$ & 0,622 & 0,623 & 0,099 & 0,099 & 6,308 & diterima \\
\hline Passion -> Love & 0,428 & 0,422 & 0,051 & 0,051 & 8,308 & diterima \\
\hline $\begin{array}{l}\text { Passion -> } \\
\text { Repurchase }\end{array}$ & 0,369 & 0,368 & 0,068 & 0,068 & 5,397 & diterima \\
\hline Trust -> Love & 0,507 & 0,511 & 0,048 & 0,048 & 10,575 & diterima \\
\hline $\begin{array}{l}\text { Trust -> } \\
\text { Repurchase }\end{array}$ & 0,402 & 0,402 & 0,075 & 0,075 & 5,373 & diterima \\
\hline \multicolumn{7}{|c|}{ Path Coefficients } \\
\hline $\begin{array}{l}\text { Love -> } \\
\text { Repurchase }\end{array}$ & 0,622 & 0,623 & 0,099 & 0,099 & 6,308 & diterima \\
\hline $\begin{array}{l}\text { Passion -> } \\
\text { Love }\end{array}$ & 0,428 & 0,422 & 0,051 & 0,051 & 8,308 & diterima \\
\hline $\begin{array}{l}\text { Passion -> } \\
\text { Repurchase }\end{array}$ & 0,103 & 0,105 & 0,074 & 0,074 & 1,392 & ditolak \\
\hline Trust -> Love & 0,507 & 0,511 & 0,048 & 0,048 & 10,575 & diterima \\
\hline $\begin{array}{l}\text { Trust -> } \\
\text { Repurchase }\end{array}$ & 0,087 & 0,083 & 0,099 & 0,099 & 0,876 & ditolak \\
\hline
\end{tabular}

Tabel 3. Total effects dan Path coefficients

Hipotesis pertama adalah brand passion berpengaruh positif dan signifikan terhadap repurchase intention. Berdasarkan tabel 3 pada total effects pengaruh antara brand passion dengan repurchase intention menunjukan nilai $\beta=0,369$ denga nilai $\mathrm{t}=$ $5,397>1,97$ (t tabel $\alpha=5 \%$ ) adalah positif dan signifikan. Konsumen yang mempunyai brand passion akan cenderung untuk melakukan pembelian kembali. Konsumen yang selalu memikirkan, membayangkan dan mengagumi merek tertentu akan cenderung untuk menggunakan merek tersebut jika suatu saat dia memutuhkan dan bahkan cenderung untuk menyampaikan dan merekomendasikan merek tersebut kepada konsumen potensial. 
Hasil penelitian ini sejalan denganBauer et al., (2007)yang menyatakan bahwa brand passion berpengaruh significant terhadap word of mouth, price premium, dan repurchase intention.Penelitian ini juga sejalan dengan Foster \& Cadogan, (2000) dan Yasin, (2013)brand memeberikan daya tarik konsumen untuk melakukan pembelian kembali atas produk atau layanan dan brand dapat menanggulangi perilaku konsumen yang disebabkan adanya ketidakstabilan harga (Foster \& Cadogan, 2000; Yasin, 2013).

Hipotesis kedua adalah brand passion berpengaruh positif dan signikan terhadap brand love. Nilai $\beta=0,428$ dengan nilai $\mathrm{t}$ statistik 8,308>1,97 (t tabel $\alpha=0,05$ ) berarti bahwa semakin konsumen bergairah terhadap suatu merek mempunyai kecenderungan konsumen akan semakin mencintai merek tersebut. Konsumen yang selalu membayangkan, mengagumi dan meikirkan suatu merek merupakan suatu tanda bahwa konsumen tersbut lagi jatuh cinta terhadap merek tersbut. Konsumen yang selalu mempunyai keinginan dan kebutuhan untuk bertemu, selalu memikirkan dan bersedia berkorban untuk yang dicintai cenderung meningkatkan derajat keterikatan secara emosional yang dipenuhi perasaan gairah karena konsumen merasa puas atas nama dagang tertentu. Penelitian ini sejalan dengan penelitian Carroll \& Ahuvia, (2006); dan Cristina et al., (2018); Karjaluoto et al., (2016) konsumen yang merasa bergairah merupakan suatu bukti bahwa konsumen mempunyai ketertarikan secara emosional dengan merek tersebut. Konsumen yang bersedia menginvestasikan sumber daya yang dimiliki, selalu mempunyai keinginan besar untuk menggunakannya, merasa terlibat dan berinteraksi dengannya pada waktu yang lalu cenderung membentuk ikatan emosional yang mengarah pada perasaan cinta karena adanya rasa intimacy (kedekatan), passion (hasrat) dan commitment (komitmen) (Steinberg, 1986).

Hipotesis ketiga adalah kepercayaan merek (brand trust) berpengaruh positif dan signifikan dengan cinta merek (brand love). koefisien $\beta=0,507$ dan nilai t statistik 10,575 $>$ t tabel 1,97 ( $\mathrm{t}$ tabel $\alpha=0,05)$, berarti bahwa hipotesis ketiga yang menyatakan bahwa ada pengaruh antara brand trust dengan brand love diterima. Semakin meningkat kepercayaan terhadap suatu merek mempunyai kecenderungan semakin meningkatkan kecintaan konsumen terhadap merek tersebut. Konsumen yang merasa bahwa suatu merek dapat dipercaya, dapat diandalkan dan merek tersebut mempunyai integritas mempunyai kecenderungan untuk meningkatkan perasaan senang, gembira dan menjadi semakin menyukai akan merek tersebut. Merek yang bisa memberikan melebihi harapan konsumen dapat mengarah pada hasil yang positif seperti sikap positif terhadap merek, komitmen dan loyalitas yang lebih kuat dan merek yang memeberikan melebihi harapan tersebut dapat menjadi kontribusi pada cinta merek, hal tersebut sejalan dengan penelitian (Albert \& Merunka, 2013; Karjaluoto et al., 2016). Hasil penelitian Albert \& Merunka, (2013) juga menyatakan akan pentingnya indentifikasi dan kepercayaan merek untuk mengembangkan cinta merek, karena ketika konsumen yakin dan percaya bahwa ia dapat mengadalkan suatu merek, maka hal tersebut akan memfasilitasi pengembangan perasaan cinta. Penelitian ini juga mendukung hasil penelitian Gultekin \& Turgut, (2005), yang menyatakan bahwa konsumen yang percaya terhadap merek meningkatkan resistensi terhadap informasi negatif tentang merek tersebut. Konsumen yang menolak informasi negatif tentang merek tertentu berarti konsumen tersebut mempunyai hubungan cinta.

Hipotesis keempat adalah brand trust berpengaruh positif dan signifikan terhadap 
repurchase intention. Berdasarkan hasil di tabel 3 pada total effects diperoleh nilai $\beta=$ 0,402 dan nilai $\mathrm{t}$ statistik $=5,373>1,97(\mathrm{t}$ tabel $\alpha=0,05)$. Nilai $\mathrm{t}$ statistik yang lebih besar dari nilai t tabel menunjukkan bahwa hipotesis yang menyatakan bahwa brand trust mempengaruhi repurchase intention adalah signifikan dan dapat diterima. Nilai $\beta$ menunjukan tanda positif berarti bahwa semakin meningkatnya kepercayaan konsumen terhdap brand maka semakin meningkatkan hasrat konsumen untuk melakukan pembelian kembali. Konsumen yang merasa bahwa merek bisa diandalankan untuk melakukan apa yang benar, dapat dipercaya dan bertanggungjawab untuk kepentingan konsumen maka konsumen cenderung untuk menggunakan merek yang sama secara terus menerus dan bahkan akan merekomendasikan pada konsumen potensial. Hasil penelitian ini mendukung penelitian (Yasin, 2013) pengalaman terhadap merek, kepercayaan terhadap merek dan komitmen mempunyai dampak yang signifikan dan positif terhadap niat pembelian.

Hipotesis kelima brand love berpengaruh positif dan signifikan terhadap repurchase intention. Berdasarkan tabel 3 pengaruh antara brand love dengan repurchase intention diperoleh nilai $\beta$ sebesar 0,622 dan nilai t sebesar 6,308 >1,97 (t tabel $\alpha=5 \%$ ) sehingga bisa disimpulkan bahwa hipotesis kelima positif signifikan. Semakin meningkatnya rasa cinta konsumen terhadap merek makan konsumen mempunyai kecenderungan untuk melakukan pembelian kembali. Konsumen yang merasa bahwa merek yang dia pakai merupakan merek yang luar biasa, merek yang membuat dia senang, merek yang membuat gembira, merek yang benar-benar mengagumkan cenderung membuat konsumen untuk terus menggunakan merek itu lagi, dan akan membeli merek itu lagi jika konsumen membutuhkan dan bahkan cenderung menjadi penyampai informasi positif kepada konsumen potensial. Kepercayaan merupakan elemen penting yang dipertimbangkan oleh konsumen untuk melakukan pembelian secara berulang. Penelitian ini juga sejalan dengan penelitian Zboja \& Voorhees, (2006) dan Gultekin \& Turgut, (2015) yang menyatakan bahwa kecintaan terhadap merek mempunyai kecenderungan konsumen untuk melakukan pembelian secara berulang. Berdasarkan penelitian Chatterjee, Sharmila C.Chaudhuri, (2005) diperoleh hasil bahwa brand trust berpengaruh signifikan dan positif terhadap pangsa pasar, berarti bahwa meningkatnya kepercayaan konsumen terhdap merek mempunyai kecenderungan meningkatkan pangsa pasar. Pangsa pasar yang meningkat dimungkinkan karena konsumen yang sudah ada atau konsumen lama melakukan pembelian kembali dan bertambahnya konsumen baru yang melakukan pembelian.

Hipotesis keenam adalah brand love sebagai mediator pengaruh antara brand passion dengan repurchase intention. Berdasarkan tabel 3 pada total effect pengaruh langsung antara brand passion dengan repurchase intention menunjuukan nilai $\beta=0,369$ dan nilai $\mathrm{t}$ statistik sebesar $5,397>1,97$ menunjukan bahwa pengaruh langsung positif dan signifikan. Nilai $\beta$ pada path coefficientssetelah adanya variabel mediasi brand loveadalah sebesar 0,103 sedangkan nilai $\mathrm{t}$ statistik sebesar 1,392< 1,97 , secara stasitistik tidak signifikan. Nilai $\beta$ yang tidak signifikan berarti dapat disimpulkan bahwa secara statistik pengaruh antara brand passion dengan repurchase intention dimediasi oleh brand love dengan sifat mediasi adalah full mediation.

Hipotesis ketuju adalah brand love sebagai mediator antara pengaruh antara brand trust dengan repurchase intention. Berdasarkan tabel 3 pada total effect pengaruh langsung antara brand trust dengan repurchase intention menunjukkan nilai $\beta=$ 0,402 dan nilai t statistik sebesar 5,373 $>1,97$ menunjukan bahwa pengaruh langsung positif 
dan signifikan. Koefisien $\beta$ pada path coefficients setelah memasukkan variabel mediasi brand love sebesar 0,087 sedangkan nilai t statistik sebesar $0,876<1,97$, secara stasitistik tidak signifikan. koefisien $\beta$ menjadi tidak signifikan setelah adanya brand love sebagai variabel mediasi berarti secara statistik pengaruh antara brand trust dengan repurchase intention dimediasi oleh brand love dengan sifat mediasi adalah full mediation.

Penelitian ini menggunakan sampel mahasiswa yang mempunyai kecenderungan usia dan preferensi yang sama, sehingga pada penelitian selanjutnya bisa dikembangkan dengan sampel yang lebih beragam dari sisi usia dan pekerjaan. Kemauan konsumen untuk melakukan pembelian kembali merupakan suatu yang sangat komplek, sehingga dengan hanya dipengaruhi oleh brand passion, brand trus yang dimediasi oleh brand love menjadikan model belum cukup memadahi.

\section{SIMPULAN}

Kesimpulan dari penelitian ini adalah bahwa brand passion, brand trust dan brand love secara langsung berpengaruh terhadap repurchase intention. Brand love menjadi variabel yang memediasi pengaruh antara brand passion, brand trus dengan repurchase intention, dengan sifat mediasi adalah full mediation.

\section{REFERENSI}

Albert, N., \& Merunka, D. (2013). The role of brand love in consumer-brand relationships. Journal of Consumer Marketing, 30(3), 258-266. https://doi.org/10.1108/07363761311328 928

Albert, N., Merunka, D., \& Valette-florence, P. (2013). Brand passion: Antecedents and consequences. In Journal of Business Research (Vol. 66). https://doi.org/10.1016/j.jbusres.2011.12
.009

Albert, N., Merunka, D., \& Valette-Florence, P. (2009). The feeling of love toward a brand: Concept and measurement. Advances in Consumer Research, 36, 300-307.

Albert, N., \& Valette-Florence, P. (2010). Measuring the Love Feeling for a Brand using Interpersonal Love Items. Journal of Marketing Development and Competitiveness, 5(1), 57-63.

Asyraf, W. M., \& Afthanorhan, B. W. (2013). A comparison of partial least square structural equation modeling (PLS-SEM) and covariance based structural equation modeling (CB-SEM) for confirmatory factor analysis. International Journal of Engineering Science and Innovative Technology (IJESIT), 2(5), 198-205.

Ballester, E. D. (2014). Development and Validation of a Brand Trust Scale. Spanish Journal of Marketing, special is(October 2011), 1-59.

Batra, R., Ahuvia, A., \& Bagozzi, R. P. (2012). Brand love. Journal of Marketing, $\quad 76(2), \quad 1-16$. https://doi.org/10.1509/jm.09.0339

Bauer, H. H., Heinrich, D., \& Martin, I. (2007). How to Create High Emotional Consumer-Brand Relationships? The Causalities of Brand Passion. Proceedings of the Australian and New Zealand Marketing Academy Conference, (1986), 2189-2198.

Bozbay, Z., Karami, A., \& Arghashi, V. (2014). the Relationship Between Brand Love and Brand Attitute. The 2nd Conference on Management \& Business, (May), 1-24.

Brady, M. K., \& Cronin, J. J. (2001). Customer Orientation: Effects on Customer Service Perceptions and Outcome Behaviors. Journal of Service Research, 3(3), 241-251. https://doi.org/10.1177/10946705013300 5 
Carroll, B. A., \& Ahuvia, A. C. (2006). Some antecedents and outcomes of brand love. Marketing Letters, 17(2), 79-89. https://doi.org/10.1007/s11002-0064219-2

Chao, W., Prybutok, V. R., \& Chenyan, X. (2011). An integrated model for customer online repurchase intention. Journal of Computer Information Systems, 52(February 2011), 14-23.

Chatterjee, Sharmila C.Chaudhuri, A. (2005). Are Trusted Brands Important? Marketing Management Journal, 15(1), $1-16$.

Chinomona, E., \& Maziriri, E. (2013). The Influence Of Brand Experience On Brand Satisfaction, Trust And Attachment In South Africa. International Business \& Economics Research Journal, 12(10), 1303-1316.

Cristina, M., Gómez, O., \& Pérez, W. G. (2018). Effects of Brand Love and Brand Equity on Repurchase Intentions of Young Consumers. International Review of Management and Marketing, 8(4), 713.

Cronin, J. J., \& Taylor, S. A. (1992). Measuring Service Quality: A Reexamination and Extension. Journal of Marketing, 56(3), 55-68. https://doi.org/10.1177/00222429920560 0304

Fetscherin, M. (2014). What Type of Relationship Do We Have With Loved Brands? Journal of Consumer Marketing, 31(6/7), 430-440. Retrieved from

http://scholarship.rollins.edu/as_facpub

Foster, B. D., \& Cadogan, J. W. (2000). Relationship selling and customer loyalty: an empirical investigation. Marketing Intelligence \& Planning, 18(4), 185-199. https://doi.org/10.1108/02634500010333 316

Grisaffe, D. B., \& Nguyen, H. P. (2011).
Antecedents of emotional attachment to brands. Journal of Business Research, 64(10), 1052-1059. https://doi.org/10.1016/j.jbusres.2010.11 .002

Gultekin, B., \& Turgut, M. U. (2005). The Critical Role of Brand Love in Clothing Brands. Journal of Business, Economics and Finance, 15(1), 1-26. https://doi.org/10.17261/pressacademia.2 01519963

Hellier, P. K., Geursen, G. M., Carr, R. A., \& Rickard, J. A. (2003). Customer Repurchase Intention: A General Structural Equation Model. European Journal of Marketing, 37(11/12), 1762 1800.

https://doi.org/10.1108/03090560310495 456

Hoeffler, S., \& Keller, K. L. (2003). The marketing advantages of strong brands. Journal of Brand Management, 10(6), 421-445.

https://doi.org/10.1057/palgrave.bm.254 0139

Joseph. Hair. JR, William C. Black, Barry J. Babin, R. E. A. (2009). Multivariate Data Analysis.

Joseph F. Hair, J., Hult, G. T. M., Ringle, C. M., \& Sarstedt, M. (2017). A Primer on Partial Least Squares Structural Equation Modeling (PLS-SEM). https://doi.org/10.1007/s10995-0121023-x [doi]

Karjaluoto, H., Munnukka, J., \& Kiuru, K. (2016). Brand love and positive word of mouth: the moderating effects of experience and price. Journal of Product and Brand Management, 25(6), 527537. https://doi.org/10.1108/JPBM-032015-0834

Keller, K. L. (2009). Building CustomerBased Brand Equity: A Blueprint for Creating Strong Brands Building Customer-Based Brand Equity: A Blueprint for Creating Strong Brands. 
Journal of Marketing Communications, 15(2-3), 139-155. https://doi.org/10.1080/13527260902757 530

Kudeshia, C., Sikdar, P., \& Mittal, A. (2016). Spreading love through fan page liking: A perspective on small scale entrepreneurs. Computers in Human Behavior, 54(August 2019), 257-270. https://doi.org/10.1016/j.chb.2015.08.00 3

Kuo, Y.-F., Wub, C.-M., \& Deng, W.-J. (2009). The relationships among service quality, perceived value, customer satisfaction, and post-purchased intention in mobile value-added services. Computers in Human Behavior, 25(4), 887-896.

Morgan, R. M., \& Hunt, S. D. (1994). The Commitment-Trust Theory of Relationship Marketing. Journal of Marketing, 58(3), 20-38. https://doi.org/10.2307/1252308

Niyomsart, S., \& Khamwon, A. (2016). Brand Love, Brand Loyalty, and Word of Mouth : a Case of Airasia. Conference of the International Journal of Arts \& Sciences, 09(October 2015), 263-268.

Pourazad, N., Pare, V., \& Saniee, A. (2015). Brand Passion: What Would Customers Do for their Favourite Brands Brand Passion: What Would Customers Do for their Favourite Brands Abstract. (October), 1-10.

Qian, S. U., Peiji, S., \& Quanfu, Y. E. (2011). An integrated Analysis Framework for Customer Vaiue, Customer Satisfactory , Switching Barriers, Repurchase Intention and Attitudinai Loyaity: Evidences from China Mobiie Data Services. Management Science and Engineering, 5(3), 135-142. https://doi.org/10.3968/j.mse.1913035X2 0110503.120

Ruiz-Ortega, M. J., Parra-Requena, G., Rodrigo-Alarcón, J., \& García-
Villaverde, P. M. (2013). Environmental dynamism and entrepreneurial orientation: The moderating role of firm's capabilities. Journal of Organizational Change Management, 26(3), 475-493. https://doi.org/10.1108/09534811311328 542

Sahin, A., Cemal, Z., \& Hakan, K. 1. (2012). The effects of brand experience and service quality on repurchase intention: The role of brand relationship quality. African Journal of Business Management, 6(45), 11190-11201. https://doi.org/10.5897/ajbm11.2164

Sekaran, U. (2003). Research Methods: A Skill Building Approach.

Skoog, M., \& Söderström, M. (2015). Antecedents and Outcomes of Brand Love: A qualitative study within the Swedish clothing industry.11, 300-313.

Steinberg, R. J. (1986). A Triangular Theory of Love. Psychological Review, 93(2), 119-135.

Tenenhaus, M., Vinzi, V. E., Chatelin, Y. M., \& Lauro, C. (2005). PLS path modeling. Computational Statistics and Data Analysis, 48(1), 159-205. https://doi.org/10.1016/j.csda.2004.03.00 5

Wang, Y., Lo, H.-P., \& Department, Y. Y. (2004). An Integrated Framework for Service Quality, Customer Value, Satisfaction: Evidence from China's Telecommunication Industry. Information Systems Frontiers, 6(4), 325-340. https://doi.org/10.1023/B

Whang, Y.-O., Allen, J., Sahoury, N., \& Zhang, H. (2004). Falling in Love with a Product: The Structure of a Romantic Consumer-Product Relationship. Korean Journal of Dermatology, 31(2), 320327.

Yasin, M. (2013). Brand Love: Mediating Role in Purchase Intentions and Wordof-Mouth. IOSR Journal of Business and Management, $\quad$ 7(2), 101-109. 


\section{Jurnal Ilmiah Manajemen dan Bisnis}

https://doi.org/10.9790/487x-072101109

Zboja, J. J., \& Voorhees, C. M. (2006). The impact of brand trust and satisfaction on retailer repurchase intentions. Journal of Services Marketing, 20(5), 381-390. https://doi.org/10.1108/08876040610691 275

ZeithamI, V. A., Berry, L. L., \& Parasuraman, A. (1996). The Behavioral Consequences of Service Quality. Journal of Marketing, 60, 31-46. 